Mediterranean Journal of Humanities mjh.akdeniz.edu.tr V/1, 2015, 89-100

\title{
Meme Kanserli Kadınlara Bakım Hizmeti Veren Hasta Yakınlarının Hastalarında ve Kendilerinde Gözledikleri Değişimi Belirlemek Amacıyla Geliştirilen Ölçeklerinin Güvenirlilik Geçerlilik Çalışması
}

\section{A Reliability and Validity Study of the Observed and Realized Changes by Care- givers for the Life of Women with Breast Cancer and for the Caregivers Life}

\begin{abstract}
Faik ARDAHAN*
A. Hande ULUDA $\breve{G}^{* *}$

Öz: Bu çalışmanın amacı; kanser tedavilerini tamamlamış meme kanserli kadınlara bakım hizmeti veren hasta yakınlarının hastaların düzenli fiziksel aktivite programına dahil olmasının hastalarında gözledikleri değişimi belirlemek amacıyla "Fiziksel Aktiviteye Dâhil Olan Meme Kanserli Kadınlara Bakım Verenlerin Hastalarında Gözlediği Değişim Ölçeği (MKHDÖ)” ve "Fiziksel Aktiviteye Dâhil Olan Meme Kanserli Kadınlara Bakım Verenlerin Kendilerinde Gözlediği Değişim Ölçeği’ni (BHVDÖ)” geliştirmek, geçerlilik ve güvenirlik çalışmasını yapmaktır. Çalışmanın örneklem grubu 16 hafta süreyle fiziksel aktivite programına gönüllü olarak katılan 20 meme kanserli kadına bakım ve refakat hizmeti veren toplam 98 hasta yakınından oluşmaktadır. Her iki ölçeğe de Açıklayıcı Faktör Analizi (AFA) için KMO ve Bartlett küresellik testleri uygulanmıştır. Ölçeğin iç tutarlılığına bakmak için AFA sonucunda oluşan alt faktörlerin Cronbach's Alpha değerleri, madde-faktör korelasyonuna bakmak için Pearson Korelasyon Testi ve sonuçlar $(\mathrm{p}<0.01)$ ve $(\mathrm{p}<0.05)$ hata payı ile sorgulanmıştır. Sonuç olarak; MKHDÖ ve BHVDÖ’nün destekleyici-yardımcı tedavi olarak düzenli fiziksel aktivite programına dahil olan meme kanserli hastalara refakat ve bakım hizmeti veren hasta yakınlarına uygulanabilirliğinin güvenilir ve uygun olduğu bulunmuştur.
\end{abstract}

Anahtar sözcükler: Meme Kanseri, Bakım Veren, Hasta Yakını, Düzenli Fiziksel Aktivite

Abstract: The purpose of this study was to develop the scales "The Observed Changes by care-givers in Life of The Breast Cancer Women in Remission Applied Regular Physical Activity Program (MKHDO)” and "The Realized Changes in Care-givers' Life who Give Patient Care for Breast Cancer Women in Remission Regular Physical Activity Program (BHVDO)”. This is a descriptive study and the sampled group consisted of 98 persons, caregivers to 20 women with breast cancer in remission who participated in a 16 weeks regular physical activity program. They were volunteers. The exploratory factor analysis, Kaiser Mayer Olkin test and Bartlett Spheritiy test were conducted for both scales. In order to analyze the data, the descriptive statistics methods, Cronbach's Alpha internal consistency test, Pearson Correlation Test for item factor correlation were applied and the results have been assessed according to the significant levels 0.01 and 0.05. As a result of this study; the scales of MKHDO and BHVDO were validated and reliable scales for the estimation of the effect of the regular physical activity program on women's life with breast cancer in remission and the effect on the life of the care-giver.

Keywords: Breast Cancer, Care-givers, Patient’s Relative, Regular Physical Activity

\footnotetext{
* Doç. Dr., Akdeniz Üniversitesi, Beden Eğitimi ve Spor Yüksek Okulu, Rekreasyon Bölümü, ardahan@akdeniz.edu.tr

**Arş. Gör., Akdeniz Üniversitesi, Beden Eğt.ve Spor Yük.Okulu, Rekreasyon Bölümü, huludag@akdeniz.edu.tr Bu çalışma 7-9 Kasım 2014 tarihlerinde Konya'da XIII. Uluslararası Spor Bilimleri Kongresi'nde Sözel Bildiri olarak sunulmuştur.
} 


\section{Meme Kanseri ve Düzenli Fiziksel Aktivite}

Kanser hastalığı tanı, teşhis, tedavi ve tedavi sonrasında hasta, hasta yakınları ve toplum için psikolojik, psikososyal sorunların yanında iş gücü kaybına da sebep olmaktadır (Bakar et al. 2014). Erkeklerde ve kadınlarda birçok türü olsa da "meme kanseri" hem gelişmekte olan hem de gelişmiş ülkelerde kadınların karşılaştı̆̆ı kanser türleri içinde \%16-23 oranında rastlanan, insidans hızları açısından tüm kanser türleri içinde üçüncü sırada yer alan önemli bir halk sağlığı sorunudur (Y1lmaz \& Atak 2014).

Kanser hastalığı, hastanın kendisi, yakın çevresi ve ailesini sosyal, duygusal, bedensel, bilişsel, manevi ve ekonomik boyutlarıyla olumsuz etkilemekte, yaşam kalitesini, yaşam doyumlarını, beklentilerini, alışkanlıklarını büyük ölçüde değiştirmektedir (Reis et al. 2006). Kanser hastal1ğında vücut kısımlarında kayıp ve disfonksiyonları için hastanın fiziksel rehabilitasyona, hastalıktan kaynaklanan korku, kaygı ve endişelerin giderilmesi için emosyenel ve psikososyal desteğe çoğu zaman ihtiyaç duyulmaktadır (Shirley $1997^{3}$; Lammers et al. 2000). Meme kanseri dâhil tüm kanserler için tanı ve tedavi süreci uzun zaman almaktadır. Hastalığın, radyoterapi ve kemoterapi başta olmak üzere diğer tüm tedavilerin neden olduğu saç dökülmesi, yorgunluk, bulantı, kusma, cilt yaraları, duygusal problemler gibi yan etkiler birey iyileşse bile sürekli takip edileceği için yaşamının geri kalanında sürekli hem birey için hem de ailesi için bask1 yaratmakta, yadsıma, inkar, depresyon, öfke, anksiyete (korku), kabullenme, umutsuzluk, tükenmişlik, uyku bozukluğu gibi bireyin ve yakın çevresinin yaşam kalitesini etkileyecek fiziksel, sosyal, psikolojik ve ekonomik değişiklikleri beraberinde getirmektedir (Arslan 2012).

Tüm kanser vakalarında tedavi birey-hekim etkileşimiyle yapılanmaktadır. Bazı hastalar sadece bilimsel tıbbi tedaviyi takip ederlerken, bazı hastalar bunu tamamen reddedip alternatif tedavi yöntemlerini kullanmaktadırlar. Birçok hasta da bilimsel tıbbi tedaviye ek olarak yardımcı ve destekleyici (adjuvan) tedavi yöntemlerini de takip etmektedir. Tamamlayıcı ve alternatif tedaviler olarak başvurulan yöntemler iki başlıkta toplanmaktadır (Mansky \& Wallerstedt 2006; Kav et al. 2008; Özçelik \& Fadıloğlu 2009; Sezgin 2011; NNCAM, 2014); (a) Ekinezya, Bitki Çayları, Balık yağı, Omega3, Köpek Balığı Kılçığı gibi Doğal ve Hayvansal Ürünler, (b) Akupunktur, Masaj Terapi, Meditasyon, Düzenli Fiziksel aktivite (Spor Terapisi), Sanat Terapisi, Müzik Terapisi, Feldenkrais Metodu, Alexander Tekniği, Nefes Egzersizleri, Osteopati, Chiropractors, Reiki, Tai Chi, Qigong, Yoga gibi Zihinsel ve Bedensel Terapiler.

Ulusal Tamamlayıcı ve Alternatif Tip Merkezi (The National Center for Complemantary and Alternative Medicine, NCCAM); yardımc1-destekleyici ve alternatif tedavileri; modern tıbbın bir parçası olarak kabul edilmeyen tedavi yöntemleri, ürünleri ve uygulamaları olarak tanımlasa da, Amerikan Kanser Birliği (American Cancer Society) ve Ulusal Kanser Enstitüsü (National Cancer Institute) kanserde alternatif tedaviyi, bilimsel tıbbın uyguladığı tedavinin yerine kullanılan uygulamalar, yardımcı ve destekleyici tedaviyi ise, bilimsel tıpla birlikte kullanılan tamamlayıcı yaklaşımlar olarak tanımlamaktadır (Özçelik \& Fadıloğlu 2009; Mansky \& Wallerstedt 2006). Tüm kanserlerde olduğu gibi meme kanseri tedavisinde tıbbi tedavinin yanında yardımc1-destekleyici ve alternatif tedaviler günümüz kanser tedavilerinde yaygın olarak kullanılmaktadır (Turna 2006).

Yapılan araştırmalara göre son yıllarda giderek yaygınlaşan (Kav et al. 2008) kanserli hastaların fiziksel ve duygusal iyi olma halini geliştirmek, hastalıktan ve kullanılan ilaçlardan kaynaklı semptomları azaltmak ve/veya bertaraf etmek için kullanılan yardımcı ve destekleyici tedavi yöntemlerinin kullanım nedenlerini (Mansky \& Wallerstedt 2006) (a) ümmin sistemi güçlendirme, (b) ağrıyı azaltma, ve (c) hastalık ve ilaçların yan etkilerini azaltma olarak sıralamışken (Özçelik \& Fadıloğlu 2009); (a) tedavi olma/sağlama, (b) kanser tedavisine destek olma, (c) kanserin yayılmasını ve tekrarlanmasını önleme, (d) geleneksel tıbbi tedavi yerine kullanma, ve (e) son bir çare olarak kullanma olarak sıralamışlardır. 
Yardımcı ve destekleyici tedavi olarak kabul edilen düzenli fiziksel aktivite yapma kronik rahatsızlık yaşayan tüm bireylerde ve sağlıklı bireylerde psikolojik, fizyolojik, psikososyal birçok fayda yaratmaktadır. Yapılan düzenli fiziksel aktivite ile bireyler, hobilerini gerçekleştirmede ve insan ilişkilerinde güçlü olma, sosyalleşme gibi altyapılar oluşturarak hem fiziksel, mental ve emosyonel sağlığını olumlu etkileyecek, hem de hayata dair mücadele etme, geleceğe dair umudunu arttıracaktır.

Meme kanseri tedavisinde ve tedavi sonrasındaki yaşam sürecinde hastalık ve kullanılan ilaçların semptomlarını gidermek veya azaltmak için başvurulan yöntemlerden biri olan düzenli fiziksel aktiviteyi esas alan birçok çalışma yapılmıştır. Meme kanserli kadınlarda yapılan prospektif ve reprospektif çalışmalarda hastalık tanı, tedavi ve tedavi sonrasında düzenli olarak yapılan aktivitenin hastalarda ölüm riskini $\% 50$ azalttığ , hayatta kalma ihtimalini arttırdığı, vücut direncini, yaşam doyumunu ve kalitesini arttırdığı, olumlu ruh hali yarattı̆g ilaçlardan kaynaklı huysuzluklarda azalma sağlandığı, depresyonu ve kaygıyı azalttığı, hastalığa karş1 bireyi güçlendirdiği, kardiyovasküler sistemi güçlendirdiği, yorgunluk ve halsizliği azalttığı, özellikle başkalarıyla bir arada olmayı sağlayacağ 1 için sosyalleşmeyi sağladığı ve arttırdığı, vücut kitle indeksini düşürdüğü, kas iskelet sistemini güçlendirdiği, ağrı eşiğini arttırdı ğı, denge problemlerini ortadan kaldırdığı, doğru diyet süreçleriyle desteklendiğinde uygun kiloya gelmeye destek olduğu, hastanın fiziksel olarak güçlenmesini sağladığı ve dolay1sıyla hastanın kendine olan güveni artırdığı, fiziksel çekiciliklerini arttırdığı ve seks yaşamlarını düzenlediği, kendi işini kendi görebilecek fiziksel yeterliliğe geldiği ve bunu koruduğu bulgulanmıştır (Courneya \& Friedenreich 1999; Lammers et al. 2000; Stevinson et al. 2004; McNeely et al. 2006; Murtie et al. 2007; Courneya \& Friedenreich 2007; Monninkhof et al. 2007; Schmitz et al. 2009; Speck et al. 2010; Brown et al. 2011; Ezzeldin \& Abdelaziz 2011; Ferrer et al. 2011; Daniel et al. 2012; Buffart et al. 2014; Rasmussen \& Laumann 2014). Bu çalışmalarda özellikle üzerinde durulan nokta hastaların fiziksel aktivite yapmaktan keyif aldıkları, aktivite sırasında ve sonrasında kendilerini iyi hissettikleri, fakat, aktivitenin yaşamlarında kalıcı olması için dış uyaranlara ihtiyaç olduğudur (Aslan 2012). Ardahan et al. (2014) yaptıkları bir çalışmada düzenli fiziksel aktiviteye katılan meme kanserli kadınların yaşam doyumlarını ve umut düzeylerini arttırdığ bulgulanmıştır. Buna ilave olarak Mutrie ve arkadaşlarının yapmış olduğu çalışmada (2007); tedavi sırasındaki erken evrede olan meme kanserli kadınlara 12 haftalık grup egzersiz programı uygulayarak kişilerdeki fonksiyonel ve psikolojik yararlarına bakılmış, sonrasında altı aylık süre ile takip edilmiştir. Kanser terapisinin fonksiyonel değerlendirilmesi (FACT) anketi, Beck depresyon ölçeği, pozitif ve negatif etki skalası, vücut kitle indeksi, yedi gün içerisinde yapmış olduğu fiziksel aktivitenin sorgulanması, 12 dakikalık yürüyüş testi ve omuz hareketliliğin değerlendirilmesi ile ölçümler alınmıştır. Mutrie ve arkadaşları yaptıkları çalışmada fiziksel aktivite aynı zamanda bireyin kendi gibi olanlarla daha fazla yakınlaşarak, sosyalleşerek grup terapisi yapma imkanı da verdiğini fonksiyonel, psikolojik ve psiko-sosyal birçok fayda yarattığını da bulgulamışlar, aktivitelerin olumlu sonuçları ile klinisyenler hastaları için grup egzersizlerini önermekte ve kanser hastaları için bu firsatların rehabilitasyon hizmetleri ile sağlanması gerektiği tavsiye edilmiştir.

Kanser hastalığının tedavi öncesi, sırası ve sonrasındaki hastaların rehabilitasyon ihtiyacının belirlenmesi ve karşılanmasında multidisipliner bir yaklaşım ve ekip çalışmasına ihtiyaç vardır. $\mathrm{Bu}$ amaçla oluşturulacak ekibin içerisinde hekim, diyetisyen, psikolog, mesleki danışman, ortez/ protez uzman1, fizyoterapist, enterostomi terapisti, hasta ve hasta yakınları yer almalıdır (Reis 2006).

Kanser hastaları, hastalığın her aşamasında fizyolojik, psikolojik, duygusal ve psikososyal anlamda nitelikli ve kapsamlı bir bakım hizmetine ihtiyaç duyan hasta grubudur. Kanser tedavisi çoğu zaman tek başına bireyin verdiği/başardığı bir mücadele değil, en yakınından en uzağına herkesin dâhil olduğu bir mücadele sürecidir. Bu süreçte başarılı olabilmek için hastanın çevresindeki kişilerden (yakın ve uzak çevresi dahil) hastanın kendisi için sosyal destek ve 
bakım için eş, anne-baba, çocuk, arkadaş, komşu, akraba ve diğer bireylerden hastanın yaşam kalitesi ve memnuniyetinin arttırılmasına yardım etmeleri ve destek olmaları istenmelidir (Reis 2006). Refakat ve bakım hizmeti sağlığı yükseltme, hastalık anında iyileşme, sosyal destek, hastanın kendisi, evi, var ise hastanın bakmakla yükümlü olduklarıyla (eş, ebeveyn, çocuk, ev hayvanı, bahçe, tarla gibi) hastalık döneminde aksayan süreci giderebilmek adına başka kişiler veya kurumlardan alınan desteklerdir (Ünsar et al. 2007). Refakat ve bakım hizmeti veren bireyler aynı zamanda hastanın sosyal destekçileridir. Sosyal destek; herhangi bir uyarandan dolayı stres altında ve/veya güç durumda olan bireye çevresindeki insanlar, kurumlar tarafindan sağlanan (a) Duygusal Destek (değer verilme, hoşlanma, sevgi, özen gösterilme gibi), (b) Araçsal Destek (para, araş-gereç ve materyal yardımı), (c) Bilgisel Destek (sorun ve sorunla başa çıkmada kullanılacak nitelikli bilgi aktarımı) ve (d) Yaygın Destek (boş vakitleri beraber geçirme, eğlenme gibi), gibi maddi ve manevi yardımlar olarak tanımlanabilir (Tuna 2010).

Kanser hastalığı çoğu zaman aile bireyleri ve hasta yakınları üzerinde gerilim ve kaygıya neden olur. Hatta kanserli hastanın kanseri öğrendiğinde yaşadığı yas sürecinin bir benzerini yaşarlar. Sevdikleri bireyin yaşadığı fizyolojik, mental ve duygusal değişikliklerin, acı ve çaresizliğin gözlemcileri ve tarafı olurlar. Bu bireyler hem kendi yaşamsal rollerini sürdürürlerken hem de hastaya refakat ve bakım hizmeti vermek, onunla anlamlı ve doyumlu düzeyde iletişim kurmak ve sosyal destek üretmek durumunda kalırlar. Bu durum onlar üzerinde çoğu zaman fiziksel ve duygusal yorgunluğa ve daha ileriki durumlarda tükenmişliğe neden olabilmektedir. Hastalığın teşhis, tedavi süreci ve sonrasında hasta yakınları çoğu zaman hastanın kendisinden daha fazla depresyon, yorgunluk, tükenmişlik, rol çatışması, anksiyete, içe kapanıklık gibi birçok sıkıntı yasadıkları ve bunlara bağlı olarak da fiziksel ve psikolojik olarak hastalık riski taşıdıkları birçok araştırmacı tarafından bulgulanmıştır (Fallowfield 1995; Fallowfield \& Jenkins 1999; Alacacioğlu 2007).

Kanser ve diğer birçok rahatsızlıklarda memnuniyet, yaşam doyumu, umut, depresyon, tükenmişlik, pozitif ve negatif etki skalası gibi psikososyal ölçekler daha çok hasta veya hastaya bakım hizmeti verenlerin (hasta yakın hemşire gibi) boyutundan sorgulanmıştır. Bunların bazıları; "Inmeli Hastalara Bakım Veren Hasta Yakınlarında Görülen Tükenmişlik Durumlarında Sosyal Desteğin Rolü” (Tuna 2010), “Jinekolojik Kanserli Hastaların Bakım ve Rehabilitasyonunda Hemşirenin Rolü” (Reis 2006), “Kanser Hastalarl ve Hasta Yakınlarının Depresyon, Umutsuzluk Ve Kaygl Düzeylerinin Değerlendirilmesi” (Alacacioğlu 2007), “Kanserli Hasta Yakınlartyla Etkileşim" (Terakye 2011), "Yoğun Bakım Servislerinde Bakım Hizmeti Veren Hasta Yakınlarının Tatmin Ölçeği” (Heyland \& Tranmer 2001), "Meme Kanseri Deneyiminin Aile ve Çevrebilimsel Özellikleri ve Çin-Amerikan Ailelerinde Yaşam Doyumu" (Tsai 2005), "Meme Kanserli Çalışan Genç Kadınlarda Bakım Hizmeti, Bir Uygulama” (Dowling 2010), "Hasta Tatmini ve Hasta-Aile Merkezli Bakım Arasındaki Illişki" (Crickmore 2010), "Yoğun Bakım Ünitesinde Yatan Hastaların Yakınlarının Memnuniyetinin Değerlendirilmesi" (Erdal et al. 2013), "Bakımda Yatan Hasta Yakınlarının Memnuniyeti” (Özdemir 2012) ve "Tedavi Sirasindaki Erken Evrede Olan Meme Kanserli Kadınlara 12 Haftalık Grup Egzersiz Programı Uygulayarak Kişilerdeki Fonksiyonel ve Psikolojik Yararlarının Sorgulanması" (Mutrie et al. 2007).

Bu çalışmaların hiçbirinde kanser hastasının hastalık öncesi, süreci ve sonrasında ona bakım hizmeti veren hastayı değerlendirmesi açısından rastlanmamıştır. Mevcut çalışmada yardımeı destekleyici tedavi olarak uygulanan düzenli fiziksel aktivitenin hastada yarattığı fiziksel, mental ve duygusal değişimi hastaya bakım hizmeti veren hasta yakınlarının bakışıyla sorgulanması, düzenli fiziksel egzersizin hastada yarattığı değişimlere bağlı olarak hasta yakınının kendisinde gözlemlediği değişimler bu çalışmanın diğer çalışmalardan farkını oluşmaktadır.

\section{Yöntem}

Araştırmanın Amacı: Bu çalışmanın amacı; kanser tedavilerini tamamlamış meme kanserli 
kadınlara bakım hizmeti veren hasta yakınlarının hastalara uygulanan düzenli fiziksel aktivite programı sonucunda hastalarında gözledikleri değişimi belirlemek amacıyla "Fiziksel Aktiviteye Dahil Olan Meme Kanserli Kadınlara Bakım Verenlerin Hastalarında Gözlediği Değişim Ölçeği (MKHDÖ)" ve “Fiziksel Aktiviteye Dahil Olan Meme Kanserli Kadınlara Bakım Verenlerin Kendilerinde Gözlediği Değişim Ölç̧eği’ni (BHVDÖ)” geliştirmektir.

Araştırma Modeli: Bu çalışma tanımlayıcı araştırma modelinde yapılmıştır. Tedavisi tamamlanmış meme kanserli kadınlara bakım hizmeti veren hasta yakınlarıyla sınırlandırılmıştır.

Örneklem Grubu: Bu çalışmanın örneklem grubu Akdeniz Üniversitesi Tıp Fakültesi, Tıbbi Onkoloji bölümünde tedavisi edilmiş meme kanserli hastalar arasından tesadüfi olarak seçilmiş, Antalya'da yaşayan, 16 haftalık süreyle hekimin önerdiği düzenli fiziksel aktivite programına gönüllü olarak katılan 20 meme kanserli kadına bakım ve refakat hizmeti veren toplam 98 hasta yakınından (eş, çocuk, anne/baba, kardeş, arkadaş, komşu ve yakın akrabalar) oluşmaktadır.

Veri Toplama Aracı: Çalışmada geliştirilen MKHDÖ ve BHVDÖ maddelerinin geliştirilmesinde, Yaşam Kalitesi Ölçeği (Quality of Life Scale), Heyland ve Tranmer (2001), Tsai (2005), Dowling (2010) ve Crickmore'un (2010) yaptıkları çalışmalarda yer alan maddelerden ve hasta yakınları ile yapılan açık uçlu-kapalı uçlu soruların olduğu yapılandırılmamış sorular sorularak elde edilen görüşmeler bir araya getirilmiş ve gruplanarak ölçek maddeleri oluşturulmuştur. Geliştirilen ölçekler, çalışmaya katılan beş hastaya bakım hizmeti veren 18 hasta yakınına uygulanmış ve dil, kapsam, açık ve anlaşılırlık boyutları açısından değerlendirilmesi istenmiştir. Elde edilen geri dönüşlerle ölçek formlarının son halleri oluşturulmuştur.

$\mathrm{Bu}$ çalışmada düzenli fiziksel aktivite programına katılan klinik tedavilerini tamamlamış meme kanserli kadınlara refakat ve bakım hizmeti sunan hasta yakınlarının fiziksel aktiviteden kaynaklı değişimleri belirlemek için iki ölçek geliştirilmiştir. Bunlardan ilki; 22 madde ve beş alt boyuttan oluşan MKHDÖ ve sekiz madde ve iki alt boyuttan oluşan BHVDÖ'dir. Birinci ölçekteki faktör isimleri; "Şikayet ve Yorgunluklarda Azalma", "Liderlik Becerisi/Başarma", "Hayata Olumlu Yaklaşım", "Güçlü Olma" ve "Kendine Güven" şeklinde verilmiştir. İkinci ölçekte faktör isimleri; "Etkin Zaman Yönetimi” ve "Hastamla Illgili Kaygl" olarak adlandırılmıştır. Ölçek maddeleri 5'li Likert ölçeği kullanılmıştır ve "1- Kesinlikle Katılmıyorum, 2Katılmıyorum, 3- Ne Katılıyorum Ne Katılmıyorum, 4- Katılıyorum, 5-Kesinlikle Katılıyorum” olarak derecelendirilmiştir.

MKHDÖ'deki; "Şikayet ve Yorgunluklarda Azalma (SY)" alt boyutu; hastanın fiziksel aktivite sonrasında, ev işi yaparken, alışveriş yaparken, bir yere giderken yaşadığı şikayet ve yorgunluğundaki azalmayı ifade eder, "Liderlik Becerisi/Başarma (LB)" alt boyutu; hastanın fiziksel aktivite sonrasında hastalığın fiziksel, psikolojik ve duygusal semptomlarını yönetmede hem kendisi için hem de kendisine bakım hizmeti verenler için ortaya koyduğu liderlik becerisindeki artış1, yeni beceriler öğrenme, başarma duygusu yaşama, birçok işi kendi kendine yapabilir olmasını ifade eder, "Hayata Olumlu Yaklaşım (HY)" alt boyutu hastanın fiziksel aktivite ile birlikte çevresine ve hayata dair yaklaşımında, güne moralle başlama, gün içerisinde daha mutlu olma, daha anlayışı olma, fiziksel sağlığı olumlu etkileme ve problemlerin çözümünde daha olumlu yaklaşımlar geliştirmesini ifade eder, "Güçlü Olma (GO)" alt boyutu ile hastanın fiziksel aktivite ile birlikte fiziksel ve ruhsal olarak güçlü hissetmesi, daha uzun süreli/mesafeli egzersiz/iş yapabilir olmasını ifade eder, "Kendine Güven (KG)" alt boyutu ile hastanın fiziksel aktivite ile birlikte hastalığa karşı olumsuz düşüncelerindeki azalmayı, hastalığa karşı kendindeki güven artışını ifade eder.

BHVDÖ’deki "Etkin Zaman Yönetimi (EZY)" alt boyutu, hasta yakınının bakım ve refakat hizmetinden kaynaklı yaşadığı iş yükündeki azalmayı, tükenmişlik düzeyindeki azalmayı, kendine daha fazla zaman ayıracak firsatları bulmasını, hasta ve çevresi ile kurduğu iletişim düzeyindeki artışı, yaşam doyumundaki artmayı ve etkinliklere daha fazla katılabilmeyi ifade eder, 
"Hastamla Illgili Kaygı (HIK)" alt boyutu hasta yakınının bu süreçle birlikte fiziksel aktivite programına katılan hastanın hastalığıyla ilgili duyduğu kaygı düzeyindeki azalmayı ve hastanın gösterdiği çabayla gurur duymasını ifade eder.

Verilerin Toplanması: Araştırmanın verileri Akdeniz Üniversitesi Temel Tıp Bilimleri Binası F Blok'ta bulunan spor salonunda 16 hafta süreyle (27 Ocak-16 Mayıs 2014) haftada üç gün düzenli fiziksel aktivite programına katılan meme kanserli kadınlara 16. Haftanın başında MKHDÖ, BHVDÖ ve hasta yakınlarının demografik özelliklerin alınacağı sorulardan oluşan anket formu verilmiş ve haftanın son günü getirilmesi istenmiştir. Toplam geri dönen 101 anket formuna edit işleminden sonra değerlendirmeye uygun 98 anket formu analize uygun olduğu için değerlendirmeye alınmıştır.

Verilerin Analizi: Araştırmanın verilerinde açıklayıcı faktör analizi (AFA) kullanılmış ve AFA ile faktörler belirlenmiştir. AFA'nın uygulanabilirliliğinin belirlenmesinde KMO ve Bartlett testlerinin sonuçları kullanılmıştır. Faktörlerin yapı geçerliliğini test etmek için maddetoplam analizi yapılmıştır. Maddelerin faktör yükleri, ortak varyans değerleri, ortalama ve standart sapma değerleri bulunmuştur. Ölçeğin iç tutarlılığına bakmak için AFA sonucunda oluşan alt faktörlerin Cronbach's Alpha değerleri, madde-faktör korelasyonuna bakmak için Pearson Corelation Testi kullanılmış ve sonuçlar $(\mathrm{p}<0.01)$ ve $(\mathrm{p}<0.05)$ hata payı ile sorgulanmiştır.

\section{Bulgular}

Çalışmada geliştirilen orijinal ölçeğe AFA yapılmış ve Varimax rotasyonu uygulanmıştır. Her iki ölçeğe ait faktör yükleri ve faktörleşme sonuçları 22 madde ve beş faktörde gruplanan; MKHDÖ için Tablo-1 de, 8 madde ve 2 faktörde gruplanan BHVDÖ için Tablo-3 de verilmiştir. MKHDÖ Madde-Alt Korelasyon Değerleri Tablo-2 de, BHVDÖ Madde-Alt Korelasyon Değerleri Tablo-4 de verilmiştir.

Tablo 1. Fiziksel Aktiviteye Dâhil Olan Meme Kanserli Kadınlara Bakım Verenlerin Hastalarında Gözlediği Değişim Ölçeği Faktör Analizi

\begin{tabular}{|c|c|c|c|c|c|c|c|c|c|}
\hline \multicolumn{5}{|c|}{ Kaiser-Mayer-Olkin Örneklem Yeterlilik Ölçümü } & \multicolumn{5}{|c|}{0,756} \\
\hline & \multicolumn{4}{|c|}{ Yaklaşık Ki-kare } & \multicolumn{5}{|c|}{1863,903} \\
\hline Bartlett Küresellik Testi & \multicolumn{4}{|c|}{ Serbestlik derecesi } & \multicolumn{5}{|c|}{231} \\
\hline & \multicolumn{4}{|c|}{ Anlamlilık } & \multicolumn{5}{|c|}{0,000} \\
\hline \multirow{2}{*}{\multicolumn{2}{|c|}{$\begin{array}{l}\text { Madde Numaraları ve } \\
\text { Madde Açıklamaları }\end{array}$}} & \multicolumn{5}{|c|}{ Faktör Yükleri } & \multirow{2}{*}{$\begin{array}{c}\text { Ortak } \\
\text { Varyans }\end{array}$} & \multirow[b]{2}{*}{$\mathbf{X}$} & \multirow[b]{2}{*}{ SS } \\
\hline & & SY & LB & HY & GO & KG & & & \\
\hline \multicolumn{2}{|c|}{ Ev işlerini yaparken yorgunlukları azaldı } & 0,757 & & & & & 0,797 & 3,55 & 0,86 \\
\hline \multicolumn{2}{|c|}{ Ev işlerini yaparken şikâyetleri azaldı } & 0,870 & & & & & 0,811 & 3,47 & 1,06 \\
\hline \multicolumn{2}{|c|}{ Alışveriş yaparken yorgunlukları azaldı } & 0,931 & & & & & 0,896 & 3,59 & 0,93 \\
\hline \multicolumn{2}{|c|}{ Fiziksel olarak şikâyetlerinde azalma oldu } & 0,813 & & & & & 0,765 & 3,84 & 0,92 \\
\hline \multicolumn{2}{|c|}{ Bir yere giderken şikâyetleri azaldı } & 0,734 & & & & & 0,750 & 3,76 & 0,94 \\
\hline \multicolumn{2}{|c|}{ Bir gruba liderlik etme becerisi arttı } & & 0,668 & & & & 0,667 & 3,82 & 0,85 \\
\hline \multicolumn{2}{|c|}{ Aile bireylerine liderlik etme becerisi arttı } & & 0,758 & & & & 0,654 & 4,06 & 0,92 \\
\hline \multicolumn{2}{|l|}{ Başarma duygusu yaşadı } & & 0,611 & & & & 0,702 & 4,35 & 0,66 \\
\hline \multicolumn{2}{|l|}{ Yeni beceriler öğrendi } & & 0,673 & & & & 0,667 & 4,18 & 0,66 \\
\hline \multicolumn{2}{|c|}{ Birçok işi kendi yapabilir hale geldi } & & 0,692 & & & & 0,718 & 4,14 & 0,70 \\
\hline \multicolumn{2}{|c|}{ D1ş görünüşünde düzelme oldu } & & 0,738 & & & & 0,713 & 4,10 & 0,79 \\
\hline \multicolumn{2}{|c|}{ Güne daha mutlu başlamasına sebep oldu } & & & 0,865 & & & 0,815 & 4,22 & 0,65 \\
\hline \multicolumn{2}{|c|}{ Gün içerisinde daha mutlu oldu } & & & 0,852 & & & 0,787 & 4,12 & 0,78 \\
\hline \multicolumn{2}{|c|}{ En yakınındaki kişilere karşı daha anlayışlı oldu } & & & 0,721 & & & 0,752 & 4,12 & 0,78 \\
\hline
\end{tabular}




\begin{tabular}{|c|c|c|c|c|c|c|c|c|}
\hline Fiziksel sağlığı olumlu etkilendi & & & 0,722 & & & 0,753 & 4,37 & 0,63 \\
\hline $\begin{array}{l}\text { Problemlerin çözümünde daha olumlu yaklaşımlar } \\
\text { ortaya koymaya başladı }\end{array}$ & & & 0,641 & & & 0,743 & 4,06 & 0,72 \\
\hline Fiziksel olarak daha güçlü hissetti & & & & 0,762 & & 0,807 & 4,22 & 0,82 \\
\hline Ruhsal olarak daha güçlü hissetti & & & & 0,794 & & 0,800 & 4,29 & 0,70 \\
\hline $\begin{array}{l}\text { Daha uzun mesafeli/süreli egzersiz/iş yapabilir } \\
\text { oldu }\end{array}$ & & & & 0,603 & & 0,738 & 4,31 & 0,84 \\
\hline $\begin{array}{l}\text { Hastalığına karşı olumsuz düşüncelerinde bir } \\
\text { azalma oldu }\end{array}$ & & & & & 0,619 & 0,722 & 4,14 & 0,73 \\
\hline Hastalığına karşı kendine olan güveni arttı & & & & & 0,816 & 0,723 & 4,31 & 0,55 \\
\hline Endişe düzeyinde azalma oldu & & & & & 0,820 & 0,751 & 3,88 & 0,80 \\
\hline Cronbach's Alpha değerleri & 0,916 & 0,884 & 0,884 & 0,809 & 0,777 & \multirow{4}{*}{\multicolumn{3}{|c|}{$\begin{array}{c}\text { Ölçeğin } \\
\text { Cronbach's Alpha } \\
\text { değeri }=0,929\end{array}$}} \\
\hline Döndürülmüş Öz Değerler & 4,104 & 3,850 & 3,850 & 3,850 & 3,850 & & & \\
\hline Döndürülmüş Varyans \%'si & 18,653 & 17,502 & 16,660 & 11,249 & 11,073 & & & \\
\hline Döndürülmüş Birikimli \% & 18,653 & 36,155 & 52,815 & 64,064 & 75,137 & & & \\
\hline
\end{tabular}

Rotasyon Metodu: Varimax with Kaiser Normalization

- Faktör-1: "SY- Şikâyet ve Yorgunluklarda Azalma" = Meme kanserli hastanın tedaviden sonra dahil olduğu düzenli fiziksel aktivite programının kişideki ev işleri yaparken, alış-veriş yaparken ve bir yere giderken yaşadıkları şikâyet ve yorgunluğun azalma düzeyinin, hasta yakını tarafından değerlendirilmesini ifade eder ve maddenin Cronbach's Alpha değeri = 0,916'dır.

- Faktör-2 "LB-Liderlik Becerisi/Başarma" = Meme kanserli hastanın tedaviden sonra dahil olduğu düzenli fiziksel aktivite programının kişide başkalarına, bir gruba, kendisine liderlik becerisindeki artışı, yeni beceriler öğrenmesini, dış görünüşündeki düzelmeyi ve başarma duygusunun hasta yakını tarafından değerlendirilmesini ifade eder ve maddenin Cronbach's Alpha değeri $=0,884$ 'dür.

- Faktör-3 "HY-Hayata Olumlu Yaklaşım" = Meme kanserli hastanın tedaviden sonra dahil olduğu düzenli fiziksel aktivite programının kișinin güne daha mutlu başlaması, gün içerisinde daha mutlu olmasını, en yakınındaki kişilere ve başkalarına karşı daha anlayışlı olmasını, fiziksel sağlığını olumlu etkilemesini ve hayata olumlu yaklaşımında ki düzeyini, hasta yakını tarafından değerlendirilmesini ifade eder ve maddenin Cronbach's Alpha değeri =0,884'dür.

- Faktör-4 “GO-Güçlü Olma” = Meme kanserli hastanın tedaviden sonra dahil olduğu düzenli fiziksel aktivite programının kişideki fiziksel, ruhsal ve duygusal güçlü olma hali ve daha uzun süreli/mesafeli iş ve egzersiz yapabilir olma düzeyinin, hasta yakını tarafından değerlendirilmesini ifade eder ve maddenin Cronbach's Alpha değeri $=0,809$ 'dur.

- Faktör-5 "KG-Kendine Güven” = Meme kanserli hastanın tedaviden sonra dahil olduğu düzenli fiziksel aktivite programının kendine güveninin, endişelerindeki azalmanın ve hastalığa karşı olumsuz düşüncelerindeki azalma düzeyinin, hasta yakını tarafından değerlendirilmesini ifade eder ve maddenin Cronbach's Alpha değeri $=0,777$ 'dir.

Tablo 2. MKHDÖ Madde-Alt boyut Korelasyon Değerleri

\begin{tabular}{|l|c|c|c|c|c|}
\hline \multirow{2}{*}{ Maddeler } & \multicolumn{4}{|c|}{ Faktörler } \\
\cline { 2 - 6 } & SY & LB & HY & GO & KG \\
\hline Ev işlerini yaparken yorgunlukları azaldı & $\mathbf{0 , 8 3 4}$ & $0,554^{* *}$ & $0,396^{* *}$ & $0,544^{* *}$ & $0,248^{*}$ \\
\hline Ev işlerini yaparken şikâyetleri azaldı & $\mathbf{0 , 8 9 0 * *}$ & $0,413^{* *}$ & $0,274^{* *}$ & $0,418^{* *}$ & $0,228^{*}$ \\
\hline Alışveriş yaparken yorgunlukları azaldı & $\mathbf{0 , 9 3 6 * *}$ & $0,374^{* *}$ & 0,181 & $0,389^{* *}$ & $0,298^{* *}$ \\
\hline Fiziksel olarak şikâyetlerinde azalma oldu & $\mathbf{0 , 8 6 4} * *$ & $0,448^{* *}$ & $0,200^{*}$ & $0,419^{* *}$ & $0,355^{* *}$ \\
\hline Bir yere giderken şikâyetleri azaldı & $\mathbf{0 , 8 0 7 * *}$ & $0,463^{* *}$ & $0,296^{* *}$ & $0,291^{* *}$ & $0,486^{* *}$ \\
\hline Bir gruba liderlik etme becerisi arttı & $0,437^{* *}$ & $\mathbf{0 , 8 2 6 * *}$ & $0,517^{* *}$ & $0,519^{* *}$ & $0,454^{* *}$ \\
\hline
\end{tabular}




\begin{tabular}{|c|c|c|c|c|c|}
\hline Aile bireylerine liderlik etme becerisi arttı & $0,388 * *$ & $0,806 * *$ & $0,415^{* *}$ & $0,396 * *$ & $0,398 * *$ \\
\hline Başarma duygusu yaşad 1 & $0,548 * *$ & $0,780 * *$ & $0,432 * *$ & $0,668 * *$ & $0,508 * *$ \\
\hline Yeni beceriler öğrendi & $0,321 * *$ & $0,761 * *$ & $0,559 * *$ & $0,334 * *$ & $0,338 * *$ \\
\hline Birçok işi kendi yapabilir hale geldi & $0,306 * *$ & $0,808 * *$ & $0,604 * *$ & $0,440 * *$ & $0,347 * *$ \\
\hline Dış görünüşünde düzelme oldu & $0,484 * *$ & $0,818 * *$ & $0,428 * *$ & $0,579 * *$ & $0,391 * *$ \\
\hline Güne daha mutlu başlamasına sebep oldu & $0,215^{*}$ & $0,472 * *$ & $0,884 * *$ & $0,377 * *$ & $0,261 * *$ \\
\hline Gün içerisinde daha mutlu oldu & $0,252 *$ & $0,477 * *$ & $0,880 * *$ & $0,330 * *$ & $0,213^{*}$ \\
\hline En yakınındaki kişilere karşı daha anlayışlı oldu & $0,369 * *$ & $0,585 * *$ & $0,853 * *$ & $0,515^{* *}$ & $0,243 *$ \\
\hline Fiziksel sağlı̆̆ı olumlu etkilendi & 0,130 & $0,463 * *$ & $0,785^{* *}$ & $0,441 * *$ & $0,393 * *$ \\
\hline $\begin{array}{l}\text { Problemlerin çözümünde daha olumlu yaklaşımlar ortaya } \\
\text { koymaya başladı }\end{array}$ & $0,285^{* *}$ & $0,517 * *$ & $0,737 * *$ & 0,165 & $0,428 * *$ \\
\hline Fiziksel olarak daha güçlü hissetti & $0,467 * *$ & $0,573 * *$ & $0,437 * *$ & $0,924 * *$ & $0,365^{* *}$ \\
\hline Ruhsal olarak daha güçlü hissetti & $0,216^{*}$ & $0,397 * *$ & $0,373 * *$ & $0,807 * *$ & $0,459 * *$ \\
\hline Daha uzun mesafeli/süreli iş ve egzersiz yapabilir oldu & $0,497 * *$ & $0,567 * *$ & $0,320 * *$ & $0,822 * *$ & 0,197 \\
\hline Hastalığına karşı olumsuz düşüncelerinde bir azalma oldu & $0,425 * *$ & $0,577 * *$ & $0,342 * *$ & $0,479 * *$ & $0,848 * *$ \\
\hline Hastalığına karşı kendine olan güveni arttı & $0,250^{*}$ & $0,300 * *$ & $0,302 * *$ & 0,145 & $0,780 * *$ \\
\hline Endişe düzeyinde azalma oldu & $0,253 *$ & $0,376^{* *}$ & $0,282 * *$ & $0,317 * *$ & $0,879 * *$ \\
\hline
\end{tabular}

$*: \mathrm{p}<0.05, * *: \mathrm{p}<0.01$

Tablo 3. Fiziksel Aktiviteye Dâhil Olan Meme Kanserli Kadınlara Bakım Verenlerin Kendilerinde Gözlediği Değişim Ölçeği Faktör Analizi

\begin{tabular}{|c|c|c|c|c|c|c|}
\hline \multicolumn{3}{|c|}{ Kaiser-Mayer-Olkin Örneklem Yeterlilik Ölçümü } & \multicolumn{4}{|c|}{0,806} \\
\hline & \multicolumn{2}{|l|}{ Yaklaşık Ki-kare } & \multicolumn{4}{|c|}{622,305} \\
\hline \multirow[t]{2}{*}{ Bartlett Küresellik Testi } & \multicolumn{2}{|l|}{ Serbestlik derecesi } & \multicolumn{4}{|c|}{28} \\
\hline & \multicolumn{2}{|l|}{ Anlaml111k } & \multicolumn{4}{|c|}{0,000} \\
\hline \multirow{2}{*}{\multicolumn{2}{|c|}{$\begin{array}{l}\text { Madde Numaraları ve } \\
\text { Madde Açıklamaları }\end{array}$}} & \multicolumn{2}{|c|}{ Faktör Yükleri } & \multirow{2}{*}{$\begin{array}{c}\text { Ortak } \\
\text { Varyans }\end{array}$} & \multirow[b]{2}{*}{$\mathbf{X}$} & \multirow[b]{2}{*}{ SS } \\
\hline & & EZY & HİK & & & \\
\hline \multicolumn{2}{|c|}{ Yakınımla ilgilenmekten kaynaklı üstümdeki iş yükü azaldı } & 0,854 & & 0,843 & 3,86 & 0,99 \\
\hline \multicolumn{2}{|c|}{ Yakınımla ilgilenmekten kaynaklı tükenmişlik düzeyim azaldı } & 0,779 & & 0,736 & 3,96 & 0,86 \\
\hline \multicolumn{2}{|c|}{ Kendime daha çok zaman ayırır oldum } & 0,875 & & 0,778 & 3,80 & 0,93 \\
\hline \multicolumn{2}{|c|}{ Yakınım ile daha iyi iletişim kurar hale geldim } & 0,831 & & 0,726 & 4,04 & 0,99 \\
\hline \multicolumn{2}{|c|}{ Yakınım ile daha fazla etkinliklere katılır hale geldim } & 0,897 & & 0,804 & 3,88 & 0,99 \\
\hline \multicolumn{2}{|l|}{ Yaşam doyumum arttı } & 0,812 & & 0,669 & 4,04 & 0,93 \\
\hline \multicolumn{2}{|c|}{ Yakınımın hastalığı ile duyduğum kaygım azaldı } & & 0,675 & 0,760 & 4,20 & 0,81 \\
\hline \multicolumn{2}{|c|}{ Yakınımın çabasıyla gurur duyuyorum } & & 0,944 & 0,891 & 4,55 & 0,58 \\
\hline \multicolumn{2}{|c|}{ Cronbach's Alpha değerleri } & 0,931 & 0,647 & \multirow{4}{*}{\multicolumn{3}{|c|}{$\begin{array}{c}\text { Ölçeğin } \\
\text { Cronbach's Alpha değeri } \\
=0,913\end{array}$}} \\
\hline \multicolumn{2}{|c|}{ Döndürülmüş Öz Değerler } & 4,560 & 1,648 & & & \\
\hline \multicolumn{2}{|c|}{ Döndürülmüş Varyans \%'si } & 57,00 & 20,60 & & & \\
\hline \multicolumn{2}{|c|}{ Döndürülmüş Birikimli \% } & 57,00 & 77,60 & & & \\
\hline
\end{tabular}

Rotasyon Metodu: Varimax with Kaiser Normalization.

- Faktör-1: “EZY- Etkin Zaman Yönetimi” = Meme kanserli hastanın tedaviden sonra dahil olduğu düzenli fiziksel aktivite programının hastaya bakım hizmeti veren kişinin kendi üstüne düşen iş yükündeki, tükenmişlik durumundaki azalmayla birlikte, etkin zaman yönetimi yapabilmeyi ve çevresindekilerle iyi iletişim kurabilmesini ifade eder ve maddenin Cronbach's Alpha değeri $=0,931$ 'dir.

- Faktör-2 "HíK- Hastamla İlgili Kaygı" = Meme kanserli hastanın tedaviden sonra dahil 
olduğu düzenli fiziksel aktivite programının hastaya bakım hizmeti veren kişinin hasta ile ilgili kaygı düzeyindeki azalmayı ve hastanın verdiği çabayla gurur duymasını ifade eder ve maddenin Cronbach's Alpha değeri = 0,647'dir.

Tablo 4. BHVDÖ Madde-Alt boyut Korelasyon Değerleri

\begin{tabular}{|l|c|c|}
\hline \multicolumn{1}{|c|}{ Maddeler } & \multicolumn{2}{c|}{ Faktörler } \\
\cline { 2 - 3 } \multicolumn{1}{c|}{ EZY } & HİK \\
\hline Yakınımla ilgilenmekten kaynaklı üstümdeki iş yükü azaldı & $\mathbf{0 , 9 1 1}$ & $0,570^{* *}$ \\
\hline Yakınımla ilgilenmekten kaynaklı tükenmişlik düzeyim azaldı & $\mathbf{0 , 8 3 4 * *}$ & $0,564^{* *}$ \\
\hline Kendime daha çok zaman ayırır oldum & $\mathbf{0 , 8 8 7 * *}$ & $0,376^{* *}$ \\
\hline Yakınım ile daha iyi iletişim kurar hale geldim & $\mathbf{0 , 8 6 0 * *}$ & $0,454^{* *}$ \\
\hline Yakınım ile daha fazla etkinliklere katılır hale geldim & $\mathbf{0 , 8 6 4 * *}$ & $0,372^{* *}$ \\
\hline Yaşam doyumum arttı & $\mathbf{0 , 8 1 6 * *}$ & $0,412^{* *}$ \\
\hline Yakınımın hastalığı ile duyduğum kaygım azaldı & $0,647^{* *}$ & $\mathbf{0 , 9 1 2}$ \\
\hline Yakı \\
\hline
\end{tabular}

$*: \mathrm{p}<0.05, * *: \mathrm{p}<0.01$

\section{Tartışma ve Sonuç}

Bu çalışmada kanser tedavilerini tamamlamış meme kanserli kadınlara refakat ve bakım hizmeti sunan hasta yakınlarının hastalara uygulanan düzenli fiziksel aktivite programı sonucunda hastalardaki gözledikleri değişimi belirlemek amacıyla MKHDÖ ve hasta yakınlarının kendi hayatlarında meydana gelen değişimi ifade etmelerini sağlayacak; BHVDÖ’yi geliştirmek amaçlanmıştır.

MKHDÖ ve BHVDÖ’ye KMO analizi yapılmış birinci ölçek için KMO değeri 0,756, ikinci ölçek için KMO değeri 0,806 olarak bulunmuştur. Bu sonuçlar KMO literatürüne bakıldığında verilerin faktör çıkarmak için uygun olduğunu göstermektedir. KMO analizinden sonra her iki veri grubuna Bartlett Küresellik Testi uygulandı ve her iki ölçek için de hesaplanan "p" değerinin $\mathrm{p}<=0.05$ olması korelasyon matrisindeki değerlerin birim matristen farklı olduğunu ve mevcut verilerden faktör çıkarmanın uygun olduğu anlamına gelmektedir (Şencan, 2005).

Yapılan bu çalışmada maddelerin her birinin ortak varyans değerlerine bakılarak örneklem büyüklüğü de değerlendirilmiştir. Maddelerin ortak varyans değerlerine bakılması örneklem büyüklüğünü belirlemede önemlidir (MacCallum et al. 1999). Buna göre araştırmanın örneklem sayısı küçük ise ortak varyans değerlerinin yüksek baz değerinden alınması gereklidir. Ölçekteki maddelerin ortak varyansları 0.6 'dan büyükse $n<100$ olsa bile araştırmanın örneklem büyüklüğünün yeterli olduğu kabul edilir (Field 2005). Bu çalışmada örneklem büyüklüğü $n=98$ olduğu için ortak varyans değeri 0.600 'nın üstündekiler alınmıştır. Bu sebeple araştırmanın örneklem grubu sayısı analiz için yeterli olma koşulunu sağlamıştır.

AFA sonucuna göre; MKHDÖ'nin beş alt boyutu ve BHVDÖ'nün iki alt boyutunun yap1 geçerliliklerini değerlendirmek için her bir maddenin her bir alt boyut ile madde korelasyon değerlendirmesinin bulunması gereklidir. Yapılan analiz sonucunda, her bir maddenin her bir faktörü oluşturan maddelerin faktörleştikleri alt boyutun dışındaki faktörlerle pozitif korelasyon olsa da faktörleştikleri alt boyutlarla daha güçlü korelasyon değeri vermesi beklenir. Bu çalışmada, Tablo-2 ve Tablo-4'de verildiği gibi madde-alt boyut korelasyon tablosunda beklenen sonuçlar elde edilmiştir. Bu sonuçlar, MKHDÖ ve BHVDÖ'deki her bir maddenin, faktörleştikleri alt faktörle ölçülmek istenen amaçla ilişkili olduğunu göstermiştir.

Çalışmada elde edilen faktör analizinde ölçeklerin maddelerinin gruplandıkları alt boyutlarının Cronbach's Alpha değerlerine bakılmış, MKHDÖ'nin 0,916 ve 0,777 arasında olduğu ve ölçeğin toplamı için 0,929 olduğu hesaplanmıştır. Bu ölçek için açılanan toplam varyansın \%75,13 olduğu bulunmuştur. Benzer şekilde; BHVDÖ’nün Cronbach's Alpha değerleri; 0,931 
ve $0,647^{\prime}$ 'dir. Ölçeğin toplamı için 0,913 olduğu hesaplanmıştır.

Düzenli fiziksel aktivite programının meme kanserli hastalara sağladığı yararların hastalara refakat ve bakım hizmeti verenler tarafından nasıl gözlemlendiğini ve bu değişimlerin refakat ve bakım hizmeti verenlerin kendi hayatlarında nasıl etkilediğinin esas alındığı bu çalışmada, meme kanserli hastalarda meydana gelen değişim 22 ayrı madde ile sorgulanmış ve bunlar beş farklı maddede gruplanmıştır. "Şikâyet ve Yorgunluklarda Azalma", "Liderlik Becerisi/Başarma", "Hayata Olumlu Yaklaşım”, "Güçlü Olma” ve "Kendine Güven" alt boyutları hastaların kendilerine sorularak elde edilen çalışmalarla uyumludur (Courneya \& Friedenreich 1999; Lammers et al. 2000; Stevinson et al. 2004; McNeely et al. 2006; Courneya \& Friedenreich, 2007; Monninkhof et al. 2007; Mutrie et al. 2007; Murtie et al. 2007; Schmitz et al. 2009; Speck et al. 2010; Brown et al. 2011; Ezzeldin \& Abdelaziz 2011; Ferrer et al. 2011; Aslan 2012; Daniel et al. 2012; Buffart et al. 2014; Rasmussen \& Laumann 2014). Diğer bir deyişle düzenli fiziksel aktivite yapılmasıyla elde edilen tüm faydaları hastaya refakat ve bakım hizmeti veren hasta yakınları kendi hastalarında gözlemişlerdir. Buna ilave olarak düzenli fiziksel aktivitenin hastaların yaşamlarına yaptı̆g katma değerle beraber hasta yakınlarının hayatlarında oluşan olumlu değişim Dowling (2010), Heyland ve Tranmer (2001), Tsai (2005) ve Terakye'nin (2011) yaptıkları çalışmaların sonuçlarıyla örtüşmektedir.

$\mathrm{Bu}$ çalışmada bulunan sonuçlara göre geliştirilen MKHDÖ ve BHVDÖ’nün düzenli fiziksel aktivite uygulanan meme kanserli hastalara refakat ve bakım hizmeti veren hasta yakınlarına uygulanabilirliğinin güvenilir ve uygun olduğu söylenebilir.

\section{KAYNAKÇA}

Alacacıŏlu A. (2007). Kanser Hastaları ve Hasta Yakınlarının Depresyon, Umutsuzluk ve Kaygl Düzeylerinin Değerlendirilmesi. Yayınlanmamış Tıbbi Onkoloji Uzmanlık Tezi. Dokuz Eylül Üniversitesi, Tıp Fakültesi, İç Hastalıkları Anabilim Dalı. İzmir 2007.

Ardahan F., Genç S. \& Uludağ A. H. (2014). "Tedavisi Tamamlanmış Meme Kanserli Kadınlarda Düzenli Fiziksel Aktivitenin Hastanın Yaşam Doyumuna ve Umut Düzeyine Etkisi”. 13. Uluslararası Spor Bilimleri Kongresi Bildiriler Kitapçı̆̆ $~ 7-9$ Kasım 2014, Konya.

Arslan D. (2012). Düzenli Egzersiz, Sanat (Origami) ve Grup Terapisinin, Remisyondaki Kanser Hastalarının Yaşam Kalitesi, Anksiyete, Depresyon, Hasta Tatmini ve Umut Düzeylerine Etkisi. Yayınlanmamış Yan Dal Uzmanlık Tezi. Akdeniz Üniversitesi Tıp Fakültesi İç Hastalıkları Anabilim Dalı Tıbbi Onkoloji Bilimdalı, Antalya 2012.

Bakar Y., Berdici B., Şahin N. \& Pala Ö. O. (2014). "Meme Kanseri ile İlişkili Lenfödem ve Tedavisi”. Journal of Breast Health 10 (2014) 6-14.

Brown J. C., Huedo-Medina T. B., Pescatello L. S., Pescatello S. M., Ferrer R. A. \& John, B. T. (2010). "Meta-Analysis Cancer Related Fatigue among Adult Cancer Survivors: A Efficacy of Exercise Interventions in Modulating”. Cancer Epidemiol Biomarkers Prev 20 (2010) 123-133. Published Online First November 4, 2010.

Buffart L. M., Ros W. J. G., Chinapaw M. J. M., Brug J., Knol D. L., Korstjens I., Weert E., Mesters I., Borne B., Hoekstra-Weebers J. E. H. M. \& May A. M. (2014). "Mediators of physical exercise for improvement in cancer survivors' quality of life”. Psycho-Oncology 23 (2014) 330-338.

Courneya K. S. \& Friedenreich C. M. (1999). "Physical Qxercise and Quality of Life Following Cancer Diagnosis: A Literature Review”. Ann Behav Med 21/2 (1999) 171-179.

Courneya K. S. \& Friedenreich C. M. (2007). "Physical Activity and Cancer Control”. Seminars in Oncology Nursing 23/4 (2007) 242-252.

Crickmore K. D. (2010). The Relationship between Patient Satisfaction and Patient and Family-Centered Care. A Dissertation In Partial Fulfillment of the Requirements for the Degree Doctor of Nursing. East Carolina University, Greenville. UMI Number: 340436.

Daniel Y. T. F., Judy W. C. H., Bryant P. H. H., Antoinette M. L., Duncan J. M., Sharron S. K, Leung E. C., Wynnie Y. Y. C., Ivy P. F. L., Sharon H. S. L., Aliki J. T. \& Kar-keung C. (2012). "Physical activity 
for cancer survivors: meta-analysis of randomised controlled trials”. BMJ 344 (2012) 1-14.

Dowling J. E. (2010). Patient Care: A Case Study of Young Working Women with Breast Cancer. A Dissertation Presented in Partial Fulfillment of the Requirements for the Degree Doctor of Philosophy. Capella University, Minneapolis 2010. UMI Number: 3396963.

Eker D., Arkar H. \& Yaldız H. (2001). “Çok Boyutlu Algılanan Sosyal Destek Ölçeğinin Gözden Geçirilmiş Formunun Faktör Yapısı Geçerlilik ve Güvenirliğì”. Türk Psikiyatri Dergisi 12/1 (2001) 17-25.

Erdal Ç., Tunalı Y., Korkmaz-Dilmen Ö., Eren-Akçıl F., Yentür E. \& Bahar M. (2013). "Yoğun Bakım Ünitesinde Yatan Hastaların Yakınlarının Memnuniyetinin Değerlendirilmesi”. Türk Yoğun Bakım Derneği Dergisi 11 (2013) 64-71. DOI: 10.4274/Tybdd.36855.

Ezzeldin M. I. \& Abdelaziz A. H. (2011). "Physical activity and survival after breast cancer diagnosis: meta-analysis of published studies”. Med Oncol 28 (2011) 753-765.

Fallowfield L. (1995). “Helping the Relatives of Patients with Cancer”. European Journal of Cancer 31/11 (1995) 1731-1732.

Fallowfield L. \& Jenkins V. (1999). "Effective Communication Skills are the Key to Good Cancer Care”. European Journal of Cancer 35/11 (1999) 592-1597.

Ferrer R. A., Huedo-Medina T. B., Johnson B. T., Ryan S. \& Pescatello L. S. (2011). "Exercise Interventions for Cancer Survivors: A Meta-Analysis of Quality of Life Outcomes”. Ann. Behav. Med 41 (2011) 32-47.

Field A. $\left(2005^{2}\right)$. Discovering Statistics Using SPSS. London $2005^{2}$.

Heyland D. K. \& Tranmer J. E. (2001). "Measuring Family Satisfaction With Care in the Intensive Care Unit: The Development of a Questionnaire and Preliminary Results”. Journal of Critical Care 16/4 (2001) 142-149.

Irwin M. L., Smith A. W., McTiernan A., Ballard-Barbash R., Cronin K., Gilliland F. D., Baumgartner R. N., Baumgartner K. B. \& Bernstein L. (2008). "Influence of Pre-and Postdiagnosis Physical Activity on Mortality in Breast Cancer Survivors: The Health, Eating, Activity, and Lifestyle Study”. J. Clin. Oncol 26 (2008) 3958-3964.

Kav S., Hanoğlu Z. \& Algier L. (2008). “Türkiyede Kanserli Hastalarda Tamamlayıcı ve Alternatif Tedavi Yöntemlerinin Kullanım: Literatür Taraması”. Uluslararası Hematoloji-Onkoloji Dergisi 1/18 (2008) 32-38.

Lammers S. E, Schaefer K. M, Ladd E. C. \& Echenberg R. (2000). "Caring for Women living with ovarian cancer: recommendations for advanced practice nurses”. Journal of Obstetric, Gynecologic, and Neonatal Nursing 26/6 (2000) 567-573.

Lammers S. E., Schaefer K. M., Ladd E. C. \& Echenberg R. (2000). "Caring for Women Living With Ovarian Cancer: Recommendations for Advanced Practice Nurses”. JOGNN 29 (2000) 567-573.

MacCallum R. C., Widaman K. F., Zhang S. \& Hong S. (1999). "Sample size in factor analysis". Psychological Methods 4/1 (1999) 84-99.

Mansyk P. J. \& Wallerstedt D. B. (2006). "Complementary Medicine in Palliative Care and Cancer Symptom Management”. Cancer J. 12 (2006) 425-43.

McNeely M. L., Campbell K. L., Rowe B. H., Klassen T. P., Mackey J. R. \& Courneya K. S. (2006). "Effects of exercise on breast cancer patients and survivors: a systematic review and meta-analysis". CMAJ 175/1 (2006) 34-41.

Monninkhof E. M., Elias S. G., Vlems F. A., Van Der Tweel I., A. Jantine Schuit A., Voskuil D. W. \& Van Leeuwen F. E. (2007). "Physical Activity and Breast Cancer A Systematic Review”. Epidemiology $18 / 1$ (2007) 137-157.

Mutrie N., Campbell A. M., Whyte F., McConnachie A., Emslie C., Lee L., Kearney N., Walker A. \& Ritchie D. (2007). "Benefits of supervised group exercise programme for women being treated for early stage breast cancer: pragmatic randomised controlled trial”. BMJ (2007) 1-7. DOI:10.1136/bmj. 39094.648553.AE.

NNCAM (The National Center for Complemantary and Alternative Medicine). (2014). http://nccam. nih.gov/health/whatiscam, erişim tarihi: 13-08-2014. 
Özçelik H. \& Fadıloğlu Ç. (2009). "Kanser Hastalarının Tamamlayıcı Ve Alternatif Tedavi Kullanım Nedenleri”. Türk Onkoloji Dergisi 24/1 (2009) 48-52.

Özdemir D. (2012). Yoğun Bakımda Yatan Hasta Yakınlarının Memnuniyeti. Yayınlanmamış Uzmanlık Tezi. İstanbul Üniversitesi İstanbul Tıp Fakültesi, Anesteziyoloji Anabilim Dalı, İstanbul.

Rasmussen M. \& Laumann K. (2014). "The role of exercise during adolescence on adult happiness and mood”. Leisure Studies 33/4 (2014) 341-356.

Reis N. (2006). "Jinekolojik Kanserli Hastaların Bakım ve Rehabilitasyonunda Hemşirenin Rolü”. Atatürk Üniversitesi Hemşirelik Yüksekokulu Dergisi 9/2 (2006) 88-97.

Reis N., Coşkun A. \& Kızılkaya-Beji N. (2006). "Jinekolojik Kanserlerde Yaşam Kalitesi ve Etkileyen Faktörler”. Atatürk Üniversitesi Hemşirelik Yüksekokulu Dergisi 9 /2 (2006) 25-35.

Schmitz K. H, Ahmed R. L., Troxel A., Cheville A., Smith R., Lewis-Grant L., Bryan C. J., WilliamsSmith C. T. \& Greene Q. P. (2009). "Weight lifting in women with breast-cancer-related lymphedema”. N Engl J Med. 361/7 (2009) 664-73.

Sezgin C. (2011). "Kanserde Bitkilerle Tedavide Örnek Uygulamalar”. Bitkilerle Tedavi Sempozyumu. 56 Haziran 2010, Zeytinburnu, İstanbul.

Shirley E. O. $\left(1997^{3}\right)$. Oncology Nursing. 3.ed. Mosby-Year Book, St. Louis $1997^{3}$.

Speck R. M., Courneya K. S., Mâsse L. C., Duval S. \& Schmitz K. H. (2010). "An update of controlled physical activity trials in cancer survivors: a systematic review and meta-analysis”. J Cancer Surviv 4 (2010) 87-100.

Stevinson C., Lawlor D. A. \& Fox K. R. (2004). "Exercise interventions for cancer patients: systematic review of controlled trials". Cancer Causes and Control 15 (2004) 1035-1056.

Şencan H. (2005). Sosyal ve Davranışsal Ölçümlerde Güvenilirlik ve Geçerlilik. Ankara 2005.

Terakye G. (2011). “Kanserli Hasta Yakınlarıyla Etkileşim”. Dokuz Eylül Üniversitesi Hemşirelik Yüksekokulu Elektronik Dergisi, DEUHYO ED 4/2 (2011) 78-82.

Tsai T. (2005). The Family and Ecological Attributes of Breast Cancer Experience and Life Satisfaction among Chinese-American Families. A dissertation submitted in partial satisfaction of the requirement for the degree Doctor of Philosophy. University of California, Los Angeles.

Tuna M. (2010). İnmeli Hastalara Bakım Veren Hasta Yakınlarında Görülen Tükenmişlik Durumunda Sosyal Desteğin Rolü. Yayınlanmamış Yüksek Lisans Tezi. Marmara Üniversitesi, Sağlık Bilimleri Enstitüsü, İç Hastalıkları Hemşireliği Anabilim Dalı, İstanbul.

Turna H. (2006). "Erken Evre Meme Kanserinde Adjuvan Kemoterapi ve Hormonal Tedavi Meme Kanseri”. Sempozyum Dizisi 54 (2006) 105-109.

Ünsar S., Yıldız Fındık Ü., Kurt S. \& Özcan H. (2007). "Kanserli Hastalarda Evde Bakım ve Semptom Kontrolü”. Firat Sağllk Hizmetleri Dergisi 2/5 (2007) 89-106.

Yılmaz M. S. \& Atak N. (2014). "Meme Kanseri Riskinin Beslenme İle İlişkili Faktörler Açısından Değerlendirilmesi”. Turk J Public Health 12/1 (2014) 51. 